Eduardo Vianna

Universidade Federal de Santa

Catarina, UFSC

E-mail: evianna@lagcc.cuny.edu

(D) http://orcid.org/0000-0002-0693-1346

\section{Anna Stetsenko}

Cuny - University of New York City E-mail: astetsenko@gc.cuny.edu

(D) https://orcid.org/0000-0003-0960-8875
Recebido em: 17/01/2019

Aprovado em: 27/08/2019
Turning Resistance into Passion for Knowledge with the Tools of Agency: Teaching-Learning about Theories of Evolution for social justice among foster youth

\section{Eduardo Vianna Anna Stetsenko}

\section{Abstract}

We discuss implementing critical-theoretical pedagogy within a collaborative transformative project in a foster care program in the U.S. to showcase the activist role of the educator in providing tools of agency for youth struggling against oppression. This project aimed at enhancing and spurring the residents' (adolescent boys') agency through collaborative learning activities. The cornerstone was to explore the ethical-political dimensions of knowledge in connection with the boys' own thematic universe, thus compelling them to take a stand on social and scientific issues in their own lives, their communities, and the society at large. The topic of evolution was chosen to critically examine erroneous and nefarious assumptions associated with a reductionist version of evolutionary theory that promotes the fallacious and racist, and quite widespread, view that race-based social inequality is biologically determined. This was a view that some boys apparently took up from social discourses and practices in their surrounds. A workshop on evolution led by the first author provided a forum for the boys to discuss their views on such contentious matters as the social ranking and presumed inequalities in human potential while confronting outrageous stereotypes about socalled "Black inferiority" and whether notions of evolution and human nature support or challenge such views.

Keywords: Education. Tools. Agency. Vygotsky. Transformative Activist Stance. Critical-theoretical Knowledge. Evolution. 
Resumo

Palavras-chave: Educação. Instrumentos. Agência. Vygotsky. Posicionamento Ativista Transformador. Conhecimento critico-teórico. Evolução.

Resumen

Palabras Claves: Educación; Herramientas. Agencia. Vygotsky. Posicionamiento Activista Transformador. Conocimiento crítico-teórico. Evolución.
Transformando Resistência em Paixão por Conhecimento com ferramentas de agência: Ensino-Aprendizagem sobre as Teorias da Evolução para a justiça social entre jovens em um abrigo estadual nos EUA

Discutimos a implementação de uma pedagogia critico-teórica dentro de um projeto colaborativo de transformação em um abrigo estadual para jovens nos EUA demonstrar o papel ativista do educador na promoção de ferramentas de agência para jovens lutando contra opressão. Este projeto tinha como meta aumentar e desenvolver a agência dos jovens através de atividades colaborativas de aprendizagem. $\mathrm{O}$ eixo central desse projeto consistiu em explorar as dimensões ético-políticas do conhecimento em conexão com o universo temático dos jovens de forma a encorajá-los a se posicionarem diante de questões sociais e científicas relacionadas a suas próprias vidas, a suas comunidades e à sociedade de modo geral. O tópico 'evolução' foi escolhido para examinar criticamente pressuposições errôneas e nefastas associadas com uma versão reducionista da teoria da evolução a qual promove a visão falaciosa e racista, embora bem disseminada, de que a desigualdade social entre raças é biologicamente determinada. Esta era a visão que alguns jovens expressavam a partir de discursos e práticas sociais ao seu redor. Uma oficina sobre evolução foi conduzida pelo primeiro autor forneceu um fórum para os jovens residentes discutirem suas visões sobre temas contenciosos como ranking e desigualdade sociais e supostas desvantagens de potencial humano e, portanto, confrontarem estereótipos ultrajantes sobre a assim chamada “inferioridade dos negros” e questionar se noções sobre evolução as bases biológicas da natureza humana sustentam ou desafiam tais visões.

Transformando resistencia en pasión por conocimiento con herramientas de agencia: enseñanza-aprendizaje sobre las Teorías de la Evolución para la justicia social entre jóvenes en un programa de cuido temporero en los Estados Unidos

Presentaremos un ejemplo de implementación de teoría critica pedagógica dentro de un proyecto colaborativo y transformativo en un programa de cuido temporero en los EU para enfatizar el rol activista del educador que provee herramientas de agencia para jóvenes luchando contra la opresión. Este proyecto estaba enfocado en mejorar y promover que los residentes (jóvenes adolescentes) desarrollen agencia a través de actividades de aprendizaje colaborativo. La base de este proyecto fue el explorar las dimensiones ético-políticas del conocimiento en conexión con el universo temático de los jóvenes, llevándolos a tomar un posicionamiento sobre temas sociales o científicos en sus vidas o en la sociedad en general. El tema de evolución se escogió para examinar críticamente las perspectivas erróneas y las presunciones nefarias asociadas con una perspectiva reduccionista de la versión de teoría de evolución que promueve una perspectiva que abunda en falsedad y racismo y promueve la noción que las inequidades sociales son un resultado de y determinados por diferencias biológicas. Esta fue una de las perspectivas que algunos jóvenes articularon a través del discurso social y las practicas que les rodean. Un taller sobre la evolución organizada por el primer autor proporcionó un foro para los jóvenes discutiren sus perspectivas en torno a temas como clasificación social y la presunción de inequidad en el potencial humano, mientras se confrontaba estereotipos indignantes que presumen una "inferioridad negra" y se questionava se nociones de evolución y fundaciones biológicas de la naturaleza humana que apoyan o nigan estas perspectivas. 


\section{Introduction $^{1}$}

In this paper, we address one of the most contested issues in critical pedagogy and education how to advance and promote progressive knowledge that interrogates and resist the status quo, while achieving this goal without imposing on students our own activist agendas. We argue that central to resolving this difficult conundrum is the emphasis on the tools of agency - making sure that we provide students not with any final answers or even a variety of established views and approaches (as a compendium of "facts") but with the tools for their own activist and agentive stances and positioning's. This is about developing a transformative activist stance on the issues, problems, and contradictions in our world and our own beingknowing-doing. This approach zooms in on the processes of students gaining access to forming their own views and voices, through the critical-theoretical tools of agency, that is, the tools of taking a stance and staking a claim on knowledge and its practices to thus being able to know and think for themselves.

This approach integrates the theme of activism into education and the processes of teaching-learning, advanced on the grounds of a transformative activist stance (or TAS; see Stetsenko, 2008, 2014, 2016). This perspective has been developed as a direct challenge to, firstly, the mechanical worldview that portrays human beings to be passively adapting to the world and-as concerns teaching-learning and knowledge-to be merely processing information received from outside, dispassionately and neutrally, much in similarity with how computers operate. Secondly, TAS aspires to resolve some of the impasses in recent sociocultural theories that capitalize on the role of culture, mediation, and social interaction in development and education. While building upon and integrating many important insights stemming from these theories, the TAS suggests steps to move beyond their underpinnings in the relational worldview and its notions about mind, knowledge, and learning as situated, relational, contextualized, embodied, enacted, and dynamic. This shift is achieved by introducing a transformative worldview premised on an onto-epistemology that centrally integrates human agency and activism in highlighting the human capacity to transform and transcend the status quo.

The TAS builds on and expands on a number of theoretical positions such as Vygotsky's cultural-historical theory, Bakhtin’s dialogical theory, Freire’s critical pedagogy, as these are further integrated with insights from recent works in feminist, ecological and critical approaches such as critical race theory. Central to transformative ontology and epistemology is the notion of the dual and ceaseless dynamics at the shifting nexus of people 
collaboratively changing their world while simultaneously bringing it—and themselves!into existence through the very

process of agentive contributing to communal transformations of existing realities. Although the notion of transformation is very familiar to scholars in the critical tradition and especially honored in Marxism, its radical implications at all levels of theorizing, including about the process of knowledge production and learning, have not been fully addressed (for details, see Stetsenko, 2014, 2016) and the TAS aspires to do just that. The central notion in TAS is that people contribute to and thus change the world and its community practices, essentially realizing them, that is, making them real — while the world is at the same time and through the same process reciprocally changing and realizing people through continuous cycles of recursive and dynamic, co-constitutive interactions. Importantly, this process takes place through individuals and communities struggling for a sought-after future that they themselves envision, imagine, and commit to. Posited in opposition to passive adaptation, while also supplanting a more active yet not fully agentive process of participation in community practices, the activist contribution to ongoing transformations of the world is rendered ontologically and epistemologically central to being-knowing-doing and, therefore, to learning and teaching.

From this position, education is always already a site of political contestation even when

it appears to be confined within the classroom walls (which in fact it never is) such as when students learn, for example, about evolution or laws of gravity, or even just the multiplication table. The argument is that even when education appears to be "merely" about teaching and learning some established "facts of science," it actually never is only about that but also, and quite centrally, about activism in a broad and quite fundamental sense. That is, education is also, at once, about activism understood as the right and ability to know for oneself within what is one's own —unique, authentic and authorial, and ever-emerging and shifting — quest to make a difference and to matter in the world. Activism thus understood is about agency and the ability to take a stand on what is going on in one's community practices and the wider world, to contest existing status quo, and to stake a claim to how things could be otherwise including what should and can be done to achieve a different and a better world.

In this broad sense, activism is about agentive and activist strivings and struggles of becoming, that is, about human worth and significance and, most critically, the right for each and every one of us to be agentive actors and de facto activists of our own lives and society, who contribute to community practices and bring them into realization, thus themselves 
coming into being, while rebelling against the status quo, contesting its rules, and righting its injustices and entrenched biases. In the context of education, activism in this broad sense is about each learner authoring knowledge and science, claiming it, making it one's own, all while becoming an agentive actor within the practices of “doing” science and what these practices actually stand for-the ongoing and uninterrupted human pursuits within the world in the full richness and complexity of its cultural-historical, sociopolitical, and ethicalvaluational dimensions. Importantly, the emphasis in this conceptualization is on the processes and practices at the intersection of individual quests of becoming with the wider social practices embodied in what we traditionally-and quite narrowly- think of as "science." According to this position, teaching-learning and education are not about transmission of knowledge and facts (a point articulated already by Dewey), and not even about participation in community practices (as in the sociocultural framework, e.g., Lave \& Wenger, 1991; for critique, see Stetsenko, 2008, 2016) but more radically, about agentive, authorial, authentic and activist contribution by each learner, and each teacher, to what are the workings of science and the practices of knowledge production.

At the level of practical implications for classroom practices and science curriculum, this approach suggests that science education needs to be about arranging for the processes in which students — and teachers too! — can agentively connect and contribute to investigative projects of science as a human endeavor while relying on the tools of activism and knowledge in coordinated pursuits of self- and world-realization as the pathways to transcending the status quo in sciences and beyond (cf. Stetsenko, 2010a). This broad conceptualization of activism posits a conception of human development and subjectivity that is radically different from the traditional views still dominant in mainstream approaches. It also posits a conception of science that is radically different from the traditional models aligned with canons of objectivism and positivism.

To illustrate this approach, we focus on the project of teaching and learning on the topic of evolution in the context of the American foster care system, which is fraught with contradictions and challenges (Vianna, Hougaard, \& Stetsenko, 2014). The curriculum for this project consisted of an interrelated series of generative themes collaboratively investigated with the residents of a group home (adolescent boys) as this project unfolded. Such themes are constituted by a "complex of ideas, concepts, hopes, doubts, values, and challenges in dialectical interaction with their opposites, striving towards plenitude” (Freire, 1970/2002, p. 101). The theme of domination versus liberation was investigated with the boys throughout this project as a germ-cell or dominant theme underpinning related but more specific themes 
(sub-units), such as notions of the biologically-based ranking of human groups and notions of limitations and inequality.

\section{Teaching about evolution in an activist key}

General outline - placing evolution in context. ${ }^{2}$ One of the propositions of TAS is that all research schools and theoretical frameworks carry with them - and, importantly, also within them, as their inherent dimensions - particular ethical orientations (systems of values and ethical endpoints). These orientations are tailored to and derivative from sociopolitical and ultimately, practical projects in which all knowledge uniquely gains its concreteness and meaning. These projects can be differentiated along the axis either of supporting (explicitly or implicitly) the status quo by taking it for granted or, alternatively, of aiming at transcending it through resistance and social transformation. These systems of values and orientations, or a sociopolitical ethos, indelibly color all other elements and dimensions of inquiries such as their ontologies and epistemologies, forming a unified ethic-onto-epistemology (see Stetsenko, 2018a)

This argument is in line with works that challenge the deeply hegemonic traditional canons of science as a pure and objective pursuit of naked evidence understood as knowledge (or 'information') purged of all human dimensions and politics - interests, conflicts, motivations, aspirations, and sociopolitical agendas. Imposed as a dogmatic canon, the traditional model of science is presently a form of hegemony that serves as one of the pillars in the neoliberal agenda and the new knowledge economy - a pillar that supports the overall sociopolitical and economic status quo and represents its sine qua non. This is no less than an imperial regime of truth - with particular models of science canonized, reified, and presented as an unquestioned, quasi-religious canon. The crude imposition of hegemonic models of science is carried out under the banner of

objectivity, validity, and scientific rigor which, it is claimed, allows for science to stay neutral. In fact, however, we are dealing with an ultra-aggressive, starkly ideological pursuit of a misleading and deeply flawed ideology of no ideology that is unmistakably political and ideological in its push for compliance with market-driven interests and managerialist ideologies.

To radically challenge such approaches, education has to focus on knowledge as a practice that contributes to particular socio-historical projects aimed either at liberation or at preserving the status quo. This approach has to be combined with the focus on the relevance of a forward-looking activist positioning vis-a-vis the future and of a commitment to social 
change in order to bring this future into reality. In application to the topic of evolution, as part of the vast array of issues related to nature versus nurture, one of the first steps is to invite learners to interrogate the history of these concepts. The materials that can be offered for this exploration include works such as by Fancher (2004) on the legacy of Francis Galton. This focus is important because Galton is the founder of a tradition connecting the concepts of nature and nurture with the topics of heredity, intelligence testing, and eugenics. Galton introduced the term "eugenics" to describe a program of selective breeding which, in his view, was "supported” by "experiments" on testing for a racial hierarchy of human capacities (Winston, 2004).

This appalling legacy needs to be made accessible to students so they can discern the kind of practices and projects that gave rise to the key debates about nature-nurture. Such an exploration makes it possible for students to discover the meaning and relevance of naturenurture concepts and related knowledge claims including vis-à-vis the context of imperialist and racist practices. This implies seeing "how five centuries of studying, classifying, and ordering humanity within an imperial context gave rise to peculiar and powerful ideas of race culture and nation [and nature-nurture] that were, in effect, conceptual instruments the West used both to divide up and educate the world” (Willinsky, 1988, p. 4). Students can be invited to explore whether and how these practices continue today including in readings on the recent rise of eugenics, essentialist biases, and biological reductionism (e.g., Allen, 2001).

In such explorations of the history of nature-nurture debates, students are invited to take a position, or active stance, on the conundrums involved, including by interrogating their own views, beliefs, and possible biases related to issues of putative "natural" hierarchy of human abilities inevitably implying racist implications. This is not about imposing readymade answers or "finalized" knowledge claims while delivering them as "givens" that cannot be contested by learners. Quite on the contrary, learners are provided with the criticaltheoretical tools to explore knowledge and its underlying practical and ethical-political premises and implications so that they themselves can stake a claim and claim a position, however preliminary and evolving, on the key conundrums involved. Students might choose to embrace biological determinism (and even contest critiques of racism and natural hierarchies) but only after they face their unavoidable implications given that "biological determinism is, in its essence, a theory of limits. It takes the current status of groups as a measure of where they should and must be even while it allows some rare individuals to rise as a consequence of their fortunate biology" (Gould, 1996, p. 60). The moral-ethical charges and ramifications of taking a position on one or the other side of debates about biological reductionism can be introduced so that students develop and claim their own position and take 
a stand. In the next section, we describe how the first author organized the project of teaching-learning the topic of evolution at a group home for boys, prefacing this with a description of the context in which this project took place ${ }^{3}$.

Context. The program, a group home, accommodated ten boys at a time, the great majority of whom came from racial and ethnic minorities. At the time he started working in the institution, the first author quickly realized a basic contradiction in the program as staff and residents were locked in an antagonistic power struggle. Typical of situations of custodialism (see Polsky, 1962, 2003 on custodialism in youth residential institutions), the residential program was caught up in a vicious circle engendered by a basic contradiction in its community practices characterized by a great deal of punishment the staff imposed on the boys, to which they responded with rebelliousness, as in their eyes those were mostly arbitrarily sanctioned. This pattern of resistance and punishment also characterized the boys' relations with their schools and foster care caseworkers, which added to the constant, at times violent, confrontations with the staff. In particular, the staff thought the boys needed discipline, control, and clinical treatment. They viewed as their job to maintain institutional practices and compliance by controlling the boys, which they did by frequently resorting to punitive measures. This view, supported by traditional developmental theories and actively promoted in mainstream child welfare and social work literature in the U.S., is grounded in clinical approaches heavily reliant on notions of psychopathology (for details about discourses in the program and a critical review of the child welfare literature in the U.S., see Vianna 2009). On their part, the boys refused to accept this view. Instead, they attributed their rebellious actions and defiant attitudes to the authoritarian and arbitrary institutional practices enacted by the staff. The boys refused to accept that state of affairs wherein they were the sole object of institutional intervention, including through various modalities of therapeutic control. Their understandable resistance took the form of rebellious non-compliance toward institutional rules without it being complemented with a clear vision for collaborative changes in the program. Interestingly, despite their antagonistic positioning, boys and staff not only frequently engaged in joint cultural practices (e.g., enjoying music and sports together, telling jokes, participating in community events) but also shared common views as a racially oppressed group (the staff was almost entirely Black).

Typical among staff's and boys' discourses was reliance on dominant, contradictory and stereotyped discourses on how to deal with a structurally racist society, which effectively prevented both staff and boys from fully sustaining their solidarity and developing common agency. For instance, both commonly ventriloquated social discourses mired in individualism 
wherein they portrayed themselves at once as victims of historically conditioned oppression and, yet, as somehow responsible for their own shortcomings due to putatively "wrong" values, such as prioritizing consumerist needs (e.g., clothes, jewelry, partying, etc.) over hard work and education. Tragically, deficit views inherent in such discourses led the staff to emphasize the values of discipline and control, which they thought to be essential to prepare Black and Latino boys to withstand the harsh reality of oppressed people in U.S. society. This view provided the rationale for the staff to act sternly with the boys, which amounted to punishing the victims of the system they knew all too well was unfair, rather than imagining viable alternatives. On their part, the boys often talked about the staff as uneducated ('ignorant', in their words) Blacks who turned against their own people (i.e., the boys) in order to 'survive' [sic] in the racist and corrupt institutions characteristic of U.S. society. Interestingly, both staff and boys at times moved back and forth between opposite positionings toward conformity and resistance. For instance, the staff sometimes identified with, praised, and even glorified acts of rebellion by Black people, including themselves; whereas the boys also identified with the staff (and other professionals, such as teachers) as role models who had succeeded in securing a dignified life against the odds faced by racial minorities. The upshot was that relationships between boys and staff, and their stances toward resisting oppression were highly ambivalent and volatile. As we discuss below, notions of race and stances toward racism played a key role in the participants' (staff and boys) positioning not only toward community practices but also toward their life agendas, thus figuring prominently in their thematic universe.

One striking aspect of the boys' thematic universe was the apparent contradiction between their stance toward learning as an imposed activity, not only as a chore assigned by their teachers but also as a curriculum bent on colonizing tendencies, and their discourse about the value of education in their lives. On the one hand, the boys, in the initial phase of this project (first year and a half), resisted learning, which they viewed as another form of control. Seeing learning as a forced chore controlled by adults, the boys seemed to lack the motivation to study, complained about the abstract and arbitrary nature of the school curriculum ('dry, dull and boring' [sic]) and, when they did their homework, would do so mechanically. Their stance toward learning blatantly contradicted their (and the staff's) discourse about education as the great equalizer. For instance, the boys actively resisted being cast as ignorant (an accusation they frequently heard from the staff). However, though virtually all participants continuously voiced their opinion about the crucial value of education, both staff and boys tended to dichotomize academic and practical knowledge, conflating the former (“book smarts”) with inert, abstract or useless information, or with 
erudition and etiquette, akin to cultural capital whose value was predicated on joining a “cultured”, white supremacist professional elite. In addition, as the first author came to realize later on, participants' ambivalence toward academic/scientific knowledge, was compounded by religious beliefs as well as by suspicions of capitalist societal practices, such as the privately run health care system, that they felt served primarily the interest of large pharmaceutical corporations rather than the well-being of the population. Overall, the boys faced a dilemma regarding their positioning toward formal knowledge. While they wished to gain knowledge and reject ignorance, they simultaneously resisted knowledge they thought served to legitimate oppression. In essence, the boys, and the staff too, struggled to make sense of academic and scientific education. While on the one hand education was seen as the pathway for a productive, dignified life, on the other it seemed a colonizing project that required conformity to the status quo, of which they were critical. Not surprisingly, a genuine desire and motivation to learn and progress in their education were severely lacking.

The project of social transformation. The first author entered the program with a theoretically-based and politically-committed vision rooted on ideals of social justice and solidarity with oppressed populations as embodied in the Vygotskian project merged with Freirean critical pedagogy as expanded by the transformative activist stance. He encountered the boys as already resisting the socially positioning power embedded into a range of interrelated institutional and social discourses (see Holland et. al. 1998), that was hegemonic in the group home, the child welfare system, in schools and the culture at large, which portrayed them as problematic and in need of being treated, that is, as the locus of change. Thus, his positioning toward the program was realized through critical analysis of the situation in the program while inviting staff and boys to launch a collaborative transformative project to radically transform and democratize community practices in the group home through a liberating educational agenda aimed at expanding the boys' agency through developing their own activist agendas. Though this project initially was met with a great deal of resistance from both staff and boys, it was the beginning of the investigation of the discourses and practices in the program (its thematic universe). This included scrutinizing each and all participants' stances and contributions to their community practices, including the first author's and the boys' (for more details, see Vianna \& Stetsenko, 2011, 2014).

The point of departure of the collaborative project consisted of the first author positioning himself in solidarity with the boys. This included advocating for them, mediating their conflicts and relationships with the staff, and listening to and validating their critical stance toward institutional practices and their emancipatory needs. In his efforts to jointly 
investigate with the boys their thematic universe, he began to create opportunities for them to expand their agency through novel collaborative activities devised with them (e.g., collective video projects, films, and trips to museums, galleries, and parks in New York City). These activities responded to the boys' desire to participate in the decisions involving them, no matter how small. Due to its democratic character, the first author's work with the boys increasingly, though not always, bypassed the need to resort to the type of authority typically invoked by the staff. Those first collaborative activities created an important developmental context for the boys that contrasted with the usual routines and gradually extended into their interactions with the staff, teachers, and with one another. Gradually, the number of incidents of noncompliance with program rules started to go down.

As the boys began to "open up" to the researcher, he began to learn from them and to witness with them, however incompletely, the extent to which they were oppressed not only in the program but also within a wide range of contexts, including their schools. Increasingly, the boys came to regard the researcher's efforts as genuinely in line with their standpoint, though initially still fraught with conflict and always requiring negotiation of multiple interests, which bolstered their respect for him and reconfigured his authority status along democratic lines. The growing possibility of dialoguing to reach mutual agreement led the boys to see the first author as an ally, which gave them a glimpse of hope that their situation could be changed and that space could be created in the program for them to exercise their agency. On this ground, the researcher began to invite the boys to develop a collective vision to together transform their community practices and break off the vicious cycle of control and rebelliousness.

The role of the first author essentially grew into posing center stage the notion of contribution to community practices as an ineluctable problem to all of them in the group home. The initial step consisted of realizing or even admitting that each person played a role, though not equitably, in shaping the practices of that community. The next step consisted in linking that to discourses articulated by participants vis-à-vis social issues and the positions enacted in them. The collaborative investigation of this universe of themes brought to the fore not only their dialectical contradictions and that "persons take equally contradictory positions: some work to maintain structures, others to change them” (Freire, 1970/2002, p. 101). Importantly, those collaborative, dialogical learning activities helped to reveal to the boys that they, too, vacillated and shifted between different, and even opposite, positions across a range of discourses, such as the ethic-political meaning of academic learning and evolution. The subsequent interrelated steps consisted in posing the problem of how those practices ought to be and, finally, committing to changing their activities in view of the emerging collective 
vision for transformed community practices, while simultaneously posing the problem of developing meaningful life agendas of contribution to society. The upshot was that the boys began developing identities as contributors to not only local practices of the group home but to the local practices of their schools, families, their cities and so on as citizens of their society and the world at large. Crucially, developing such identities came to rely on learning to critically examine social discourses and practices. This resulted in increasing integration and an ever-expanding sense of their sought-after future, which broadened the boys' interests and learning goals as part and parcel of their desire and need to change the world, thus constituting themselves as agents of change.

Teaching-learning about evolution. The resulting alternative learning context created the conditions to introduce critical social theories to the boys. Following critical-theoretical pedagogy, those workshops focused on scientific concepts taught in schools, including critical-theoretical analyses of social practices. Integrating and expanding Vygotskian systemic-theoretical instruction (see Davydov, 1990; Gal'perin, 1989; and for expansion, Arievitch, 2017; Arievitch \& Stetsenko, 2000) and Freirean critical pedagogy, the cornerstone of critical-theoretical pedagogy premised on TAS is to provide conceptual tools for youth to define their present location within social practices and understand key contradictions while developing a collective vision (endpoint) about how to transform these practices and themselves. Because of this combination of systemic-theoretical and critical dimensions, we refer to these activities as critical-theoretical pedagogy (see Vianna \& Stetsenko, 2011).

We paid special attention to the concept of evolution, a topic fraught with ideological connotations and racial stereotypes. The topic of evolution was highly controversial among the boys and their communities, as it seemed to present a clash between scientific and religious views. Moreover, the theory of evolution seemed to be connected with grotesque and starkly racist notions of a supposed "Black inferiority”. Consistent with our transformative activist stance, we did not remain neutral and taught this topic in a way that directly addressed contradictions between scientific knowledge and its political uses, while empowering the boys to reclaim this knowledge for egalitarian and emancipatory purposes. Moving through politics (not avoiding it), we worked to reclaim and re-politicize the notion of evolution from reductionist and reactionary connotations of inherited constraints and gifts by teaching a dialectical view of evolution that posits nature as a continuous and limitless process that unites all living forms into one inter-related process without constraints imposed from outside by any rigid commands or predetermined design specifications (cf. Stetsenko, 2011, 2018b,c). 
Evolution was the most mystified and controversial topic in the program, which some boys and some staff members vehemently opposed (on religious grounds) but could not be ignored as the boys encountered in their school learning as well as in our frequent trips to the American Museum of Natural History (AMNH) in New York City. Confusion about this topic had surfaced as soon as the first author began working with the boys on scientific themes. One day, while viewing a video about mammals, a boy became very upset and started to scream against the evolutionary perspective presented in the video saying that evolution was absurd. He said that he could not have possibly descended from monkeys. “Monkeys? Monkeys?” he kept repeating. Talking with him afterward, the first author learned that the reason for the boy's objection was his belief that the theory of evolution was a way of putting black people down by implying that they are somehow more closely related to the great apes than Whites. This was plainly evident in the boys' demeaning jokes with one another about their “direct ties” to apes as African-Americans whenever we visited the human evolution dioramas at the AMNH (e.g., the usual jokes were to say that a doll representing an Australopithecus afarensis was their peer's grandmother or that another looked like one of their youth counselors). In fact, derogatory jokes about Africans as supposedly "primitive”, even "ape-like" people were painfully frequent against the two youth counselors (staff members) who were from Nigeria. In his first year in the program, the first author was pained to overhear the boys countless times call those counselors “African Monkeys.”

Thus, what the first author learned from the boys was that there was much more than only religious faith issues involved in their confusion about and resistance towards evolution. Indeed, those boys seemed to have been resisting distorted, racialized views of evolution that put Blacks at the bottom of a purported hierarchy of human races, akin to social Darwinism. It was no wonder that religious discourses on creationism seemed better suited to those boys and staff in their quest for empowerment for the Black community, as the interrelated topics of evolution and 'nature versus nurture' were not taught in a historical context that directly addresses the contested and racist legacy of biologically reductionist theories within colonialist discourses and practices.

The controversial history of theories of evolution, the main contentious issues underlying the Darwinian theory of evolution, and its implication for understanding human nature and social practices were thoroughly discussed with the boys. Before teaching human evolution, the first author introduced the boys to the topic of evolution in general with a focus on the material evidence for it, including some of the findings that puzzled early scientists. For instance, the boys were fascinated by the fact that fossils of seashells had been found on mountaintops indicating that certain areas of the planet had undergone profound 
environmental changes, which forced species to change in order to adapt. They were also intrigued by the fact that Darwin had found fossils of extinct animals that looked like giant versions of modern animals (e.g., giant fossils of armadillos). Simultaneously, in trips to the AMNH Human Evolution hall, the boys were confronted with the material evidence for human evolution (e.g., noticing differences in skull size and brow ridges halfway between an ape's and a modern human's in order to tell it was the fossil of an early human).

Then, based in works in Vygotsky’s tradition (e.g., Hedegaard, 1996; cf. Stetsenko \& Vianna, 2009), the boys learned about human evolution by systematically relating paleontological findings (e.g., presented in a video) by constructing a germ-cell model with which to systematically compare the evolution of six species of early human in terms of interrelated transformations in finding food, innovations (tools), physical changes, and social relations. Comparing different evolutionary trajectories of species that co-habited Africa, the boys learned about the relational and open-ended nature of evolution as species changed to adapt to changing environments based on their previous adaptations. They were fascinated to learn about the process that drove early humans to tool-making - how a severe drought forced Homo habilis to look for new ways of eating, such as using rocks to crack bones open and eat the marrow (in contrast with a co-existing species whose powerful teeth allowed them to eat big roots, thus sparing them from the effects of such environmental change). Importantly, the boys understood the central role of tool making in human evolution as it substantially changed the way early humans lived and related to one another. Based on an example of a collective hunt, coordinated to allow individuals to perform separate yet complementary functions (e.g., Neanderthals hunting mammoths by climbing a cliff from which they together threw a big rock down to kill one of the animals in the herd moving under the cliff), they learned about how division of labor emerged along with the need for communication and task coordination. In sum, the boys learned how human evolution culminated in labor based in the collective use of tools as the life-activity of humans that became the driving force of their development.

This dialectical view of evolution, and human evolution, in particular, allowed the boys to understand what Darwin referred to as the grandeur of evolutionary thinking, which has to do with an "intimate interconnectedness of each and every form of life with all of life; the interconnectedness of all that is alive with all that ever was, is, or ever will be alive" (Stetsenko, 2011, p. 31). This view posits nature as a continuous and limitless process that stretches from the past into the future without breaks, thus uniting all living forms into one inter-related process, one web of connections without constraints imposed from outside by any rigid commands or predetermined design specifications. The boys engaged this view, 
which contrasts sharply and disavows the idea of human nature as incontestable and inert that is, as existing apart, prior to, and independent from social practices, politics, and culture as a powerful tool to refute the contradictory ways of thinking about social inequality and injustice that are supposed to represent inevitable outcomes of some blind forces of evolution and natural selection.

Based on this view, the first author could explore with the boys the anti-racist implications of the dialectical views on the theory of evolution. One of the arguments they examined was that to explain unequal distribution of recourses or achievement gaps in disadvantaged populations, including their own, by forces of nature (Charlesworth, 1992) is to "grossly mischaracterize what in reality are the workings of particular social and political institutions that create colossally increasing wealth surrounded by disastrously increasing poverty" (Stetsenko, 2011, p.39). In other words, evolution was taught in such a way as to turn reactionary and racist misconceptions of evolution on their head by disclosing that early humans were not the ancestors of Black people alone (or more directly of them as compared to Whites), but of the entire humankind, making us all related as one single human race of common ancestry without any hierarchies. In sum, our approach deconstructed traditional teachings of evolution that dehumanize minorities, undermine common human bonds, assign immutable pseudo-characteristics to marginalized groups of people, and ultimately promote hierarchies and inequality.

Importantly, these ideas were agentively taken up by the boys themselves who formed their own views on many topics such as, and especially, race relations, while applying knowledge about social equality of all humans in light of the dialectics of human evolution. In particular, the knowledge of evolution was applied in viewing their potential, and the potential of racial minorities, as not in any way predetermined and instead, as infinite and open-ended, with no restrictions imposed by any kind of "natural ceilings" on what they can achieve, implying profound equality and solidarity across all society members (cf. Stetsenko, 2009, 2017b, 2018b,c) — with this potential squashed and impeded by oppressive capitalist structures such as in the group home.

Remarkably, the boys' discourses on race relations changed significantly. The use of racist (and sexist) terms depicting Blacks as somehow inherently and "naturally inferior," common in insults and jokes the boys used to exchange among themselves and with the youth counselors (especially the ones from Africa), virtually disappeared from the boys' repertoire. By the time the workshops had been completed the first author no longer heard the "N-word" being uttered in the institution, not even as a term of endearment, as used to be common before. Moreover, reliance on racially charged discourses to justify their own shortcomings, 
which the first author had observed many times in the initial phase of this work, also dropped out of the boys' repertoire.

\section{Findings and Discussion: Critical-Theoretical Knowledge as a Tool of Agency}

The concept of evolution, as well as others, taught in a critical-theoretical manner to foster youth, served as tools to break down fatalism by challenging traditional individualist, essentialist, reductionist ideology embodied in millennia of Western 'canonical' knowledge. As we mentioned earlier in the paper, this topic was not a stand-alone exploration but part of a larger curriculum of critical theories that the first author made available to the boys. As we have described elsewhere (Vianna, 2009; Vianna \& Stetsenko, 2011, 2014), the first author made Freire's Pedagogy of the Oppressed available to the boys, especially the older ones, with whom he read this book. Many boys found Freire's concept of the "banking” type of education - the assumption that knowledge can be poured into individual heads like deposits at a bank-very revealing. It allowed them to transform their understanding of their educational shortcomings from solely an individual failure to the instantiation of a societal problem embedded in a broad system of historically institutionalized inequitable social relations and practices.

Aided by critical-theoretical concepts in the service of their agency, that is, as tools of their own agency, the boys' views of race relations and of institutional practices as impossible to change began to give way to an increased desire to better analyze such practices in order to transform them. Through the agentive tools of critical-theoretical knowledge they could now examine-and reflect on their stance toward — the manifold contradictions in their community practices while drawing systematic connections among histories and layers in social practices and exploring possibilities for a collective agency. As the boys developed their agentive and activist transformative stance, a drastic change in themselves and their institution started to unfold. For instance, the boys began to question the value of deterministic views that posited society as inevitably stratified and normative with some groups dominating others. Thus, they came to recognize that such views, which imply that hopes for social change are futile, in fact, promoted the status quo and an individualistic stance, thus, impeding the goal of constructing egalitarian community practices. This new understanding spurred the boys' commitment to fight such stereotypes and change their community practices.

Synergistically, deconstructing and reconstructing views of human nature through learning about different conceptions of evolution was crucial for reimagining social practices, including by disclosing how our views and knowledge contribute to them by connecting 
knowledge claims to social agendas with ethical-political underpinnings. Learning about evolution contributed to opening up or changing the boys' imagination by clarifying and demystifying their views of human nature especially as relates to biology and race. Learning a dialectical theory of evolution changed the boys' view of race and thus of society and themselves. Thus, theoretical discussions of views about human nature were central in this project because it revealed to the boys the underlying assumptions behind two opposite views of evolution and how they afford/offer different ethic-political stances toward human equality and race-based social inequality. This entailed a quest for knowledge which involves 'making one's mind' and 'knowing for oneself' about contested views on issues immediately relevant to the boys such as racism and race relations.

This approach to teaching and learning about evolution worked as a powerful tool to help the boys to overcome their (and the staff's) view of abstract concepts as irrelevant or, in this case, even apparently contrary to their goals. Taught in conjunction with other content areas, such as learning arithmetic concepts as embodiments of and tools for practical operations; the dynamically evolving and continuously expanded universe, including the formation of the Earth; and political economy, addressed through the prism of consumption and advertising (with special focus on how corporations target adolescents), this criticaltheoretical knowledge allowed the boys to overcome their mystified view of scientific knowledge production by mastering theoretical generalization as an empowering tool for their own quests and historical becoming.

The results of this approach were dramatic and far-reaching. As the boys' criticaltheoretical knowledge increased, they began to draw broad connections among a range of phenomena that disclosed previously unrecognized contradictions and underlying political implications. One compelling example relates to some of the older boys' reading of the critical social theory, in particular, Freire's Pedagogy of the Oppressed (1970/2002), in tandem with the sequence of critical-theoretical learning workshops mentioned. In a mutually illuminating process, Freire's critique of the banking type of education empowered them by revealing academic underachievement as related to educational practices (thus demystifying individualist and naturalist deficit accounts) while their engagement in critical-theoretical learning, through which they were able to grasp abstract concepts as meaningful tools that can be used for emancipatory purposes, further empowered them to commit to this type of learning, thus taking a stand toward transforming institutional practices. On the one hand, learning to view the practices of schooling within a broader social and historical context (e.g., through Freire's pedagogy of the oppressed) helped the boys better comprehend the situation of their families and develop a deeper grasp of oppression as a systemic problem. On the 
other hand, learning to reclaim theoretical knowledge, such as the concept of evolution, as a tool to locate themselves within cultural-historical and political processes, including taking a stand toward contested scientific views, inspired and empowered them as learners and as actors in their community committed to a collective project to challenge and transform social processes and structures in a quest to overcome their status quo-including by taking away their stereotypes and racialized views.

These changes in community practices, instigated by the boy's changes in their own activities, amounted to nothing short of a full-blown identity transformation. A key aspect of such deeply personal but at the same time profoundly social changes (as blended rather than opposed; on the concepts of personhood as profoundly social and "collectividual" see Stetsenko, 2012, 2013; Stetsenko \& Arievitch, 2004) became manifested in how the boys began applying and authoring critical-theoretical knowledge in their new attitudes and stances toward what they (and the staff) once viewed as purely academic knowledge (i.e., for only "book smart people”). Their changed relation to learning and acquiring theoretical knowledge was not about merely embracing academic knowledge in an uncritical way, as would be in line with what they were often told was the only path toward financial stability and upward mobility, which they used to rightfully resist on the grounds of refusing to capitulate to a White supremacist ideology. Indeed, their newfound meaning of learning and knowledge did not do away with their initial critical stance toward academic learning, which they knew served to support discriminatory social discourses and practices, and thus which they resisted. Instead, their critical stance, once channeled solely through resistance, was dialectically superseded, that is, at once preserved yet transformed and expanded into passion to learn in order to position themselves, in an empowered knowledgeable manner, vis-à-vis an increasing range of issues in their own lives and a set of broader social issues (while interrelating these issues as mutually co-constituted).

This was a transformative process in which the boys were coming about as agentive actors of community practices, with their own quests of becoming, rather than as passive recipients of established dogmas (knowledge, facts, etc., which they understandably staunchly resisted), who are supposed to only adapt to and follow with the status quo. Instead, the boys began relating to knowledge and the social practices behind it (especially, their ethicalpolitical underpinnings) in deeply personal ways, while making knowledge their own, that is, making knowledge part of their own strivings and quests for justice, humanity, and equality. In the process, the boys were able to stake their own claim, with the help of the newly acquired knowledge, on the profoundly contradictory practices in their lives and their 
community practices and thus, to take an agentive stance of striving to make a difference in these contexts and practices. In this way, the boys were able to not only make knowledge matter to them but also, to make themselves matter as active agents of social practices - in a synergistically interconnected process of their historical becoming as actors of social change (see Stetsenko, 2016, for a detailed discussion of such dynamics at the intersection of teaching-learning and development). This process was facilitated by the provision of the critical-theoretical tools of an agency that afforded to disclose the hidden agendas behind knowledge, including various interpretations of the theory of evolution.

In hindsight, it looks as though the boys all of a sudden ${ }^{4}$ wanted to take a position toward and stake their claim on all kinds of social issues, not only those currently in the news, such as the U.S. wars on the Middle-East, which they opposed, as well as on immigration, climate change, endangered species, etc., but also toward historical events which they increasingly cared about as they realized their power to help us understand how things got to be the way they are in present societal practices. For instance, in the last year of this project the first author witnessed the boys' deep interest in critically debating Columbus's legacy (e.g., was he an explorer or colonizer?). For about two weeks the boys had exciting discussions around this issue, which even their peers who were not currently learning about that in school, as well as the staff, were drawn into. Whereas earlier such discussions had appeared to them to be mere academic diversions devoid of any practical value, and thus not at all worth spending effort on, they now became not only motivating but highly appealing due to them being fraught with conflicting ethical-political connotations in need of passionate deliberation and resolution. Moreover, as these discussions attested to, the boys felt an urgent need to take on responsibility for taking aside and making up their own minds on this topic, which they apparently now could not abstain from. The colonial bias in discourses, including theoretical concepts, became a preferred target of critical scrutiny for the boys, and they became fascinated to learn the history of minority groups, not just of African-Americans and Latinos, but also of Native Americans, the growing islamophobia at the time, and many other social issues they found appalling.

Gradually, boys and staff together, in a remarkable feat of a newly found solidarity, managed to tackle and even, at least partly, dismantle the hierarchical power structure in the group home based on authoritarian control and its corollary system of favoritism and spurious alliances. In this process, the vicious cycle was broken as the contradiction between control and resistance gave way to a new power dynamic based on solidarity and collaboration in efforts to transcend and transform the status quo. Furthermore, they began to grasp that sheer resistance might be self-defeating because it reinforced the staff's view that they suffered 
from emotional disturbances and, in effect, sustained the existing status quo. This critical analysis mediated by critical-theoretical concepts allowed the boys to recognize how they and the staff were locked in an "additive" misconception of empowerment, in which gains in an agency on one side implied loss of agency on the other. This instigated the boys to reimagine their community practices in ways that would expand their agency synergistically on the grounds of solidarity. Thus, critical-theoretical teaching-learning emerged as a central activity in the program, driven by the boys' desire to acquire conceptual tools for their own historical becoming as agents of their communities and for social change in these communities. Insofar as these concepts enabled the boys to see the possibility of change and the practical value to what they used to view as useless, “abstract” knowledge, this knowledge was turned into tools of their own agency and identity by spurring their activist positioning toward community practices, learning, and their lives now and as extending into the future (Vianna, 2009; Vianna \& Stetsenko, 2011).

Overall, our example of teaching-learning with the critical-theoretical tools of agency (using the theory of evolution case), we hope, illustrates how this process can be about agentive and activist strivings and struggles of becoming, that is and most critically, about the right for each and every one of us to be agentive actors of our own lives and of society at large, who contribute to community practices and bring them into realization, thus ourselves coming into being, while rebelling against the status quo, contesting its rules, and righting its injustices and entrenched biases. We hope to have highlighted how education can be about learners and all of us authoring knowledge, claiming it, making it our own, all while becoming agentive actors within the practices of knowledge production, our lives, and our community practices.

\footnotetext{
Notas

${ }^{1}$ This section is based on Stetsenko (2017a, 2018a)

2 This subsection is based on Vianna \& Stetsenko (2017)

3 This was the first author's original study, carried out under the supervision of the second author as his doctoral advisor at the time.

${ }^{4}$ As we described here and elsewhere, this was a long process of transformation, though quite dynamic, with long periods of slow changes and periods where the change took place quite rapidly and dramatically.
}

\section{References}

ALLEN, G. E. (2001). Essays on science and society: Is a new eugenics afoot? Science, 294 (5540), 59- 61. doi:10.1126/science.1066325. 
ARIEVITCH, I. M. (2017). Beyond the brain: An agentive activity perspective on mind, development, and learning. Boston/Rotterdam: Sense.

ARIEVITCH, I. M. \& Stetsenko, A. (2000). The quality of cultural tools and cognitive development: Gal'perin's perspective and its implications. Human Development, 43, 69-92.

CHARLESWORTH, W.R. (1992). Darwin and developmental psychology: Past and present. Developmental Psychology, 28, 5-16.

DAVYDOV, V. V. (1990). Types of generalizations in instruction. Reston, VA: National Council of Teachers of Mathematics.

FANCHER, R. (2004). The concept of race in the life and thought of Francis Galton. In A. Winston (Ed.), Defining difference: Race and racism in the history of psychology, (pp. 49-75). Washington, DC, US: American Psychological Association

FREIRE, P. (1970/2002). Pedagogy of the oppressed. New York, NY: Continuum. (Original work published 1970).

GALPERIN, P. Ia. (1989). Study of the intellectual development of the child. Soviet Psychology, 27, 26-44. (Original work published 1969).

GOULD, S. J. (1996). The mismeasure of man ( $2^{\text {nd }}$ edition). New York: W.W. Norton \& Company.

HEDEGAARD, M. (1996). How instruction influences children's concepts of evolution. Mind, Culture, and Activity, 3 (1), 11-24.

HOLLAND, D., LACHICOTTE, W., SKINNER, D., \& Cain, C. (1998). Identity and agency in cultural worlds. Cambridge MA: Harvard University Press.

LAVE, J., \& WENGER, E. (1991). Situated learning: Legitimate peripheral participation. New York, NY: Cambridge University Press.

POLSKY H. W. \& BERGER, R. (2003). From custodialism to community. University Press.

POLSKY, H. W. (1962). Cottage six: The social system of delinquent boys in residential treatment.Malabar, FL: Krieger Publisher.

STETSENKO, A. (2018a). Research and activist projects of resistance: The ethical-political foundations for a transformative ethico-onto-epistemology. Learning, Culture and Social Interaction. https://doi.org/10.1016/j.lcsi.2018.04.002

STETSENKO, A. (2018b). Natureculture in a transformative worldview: Moving beyond the "interactionist consensus." In G. Jovanovich and C. Ratner (Eds.), The Challenges of Cultural Psychology (pp. 37-57). London: Routledge.

STETSENKO, A. (2018c). Confronting biological reductionism from a social justice agenda: Transformative agency and activist stance. Literacy Research: Theory, Method, \& Practice. https://doi.org/10.1177/2381336918787531

STETSENKO, A. (2017a). Science education and transformative activist stance: Activism as a quest for becoming via authentic-authorial contribution to communal practices. In L. Bryan and K. Tobin (Eds.), 13 Questions: Reframing Education's Conversation: Science (pp. 33-47). NY: Peter Lang. 
STETSENKO, A. (2017b). Putting the radical notion of equality in the service of disrupting inequality in education: Research findings and conceptual advances on the infinity of human potential. Review of Research in Education, 41, 112-135.

STETSENKO, A. (2016). The transformative mind: Expanding Vygotsky's approach to development and education. New York, NY: Cambridge University Press.

STETSENKO, A. (2014). Transformative activist stance for education: Inventing the future in moving beyond the status quo. In T. Corcoran (Ed.), Psychology in Education: Critical Theory Practice (pp. 181-198). Rotterdam, The Netherlands: Sense Publishers.

STETSENKO, A. (2013). The challenge of individuality in cultural-historical activity theory: "Collectividual" dialectics from a transformative activist stance. Outlines - Critical Practice Studies, 14(2), 7-28.

STETSENKO, A. (2012). Personhood: An activist project of historical Becoming through collaborative

pursuits of social transformation. New Ideas in Psychology, 30, 144-153.

STETSENKO, A. (2011). Darwin and Vygotsky on development: An exegesis on human nature. In M. Kontopodis, Ch. Wulf \& B. Fichtner (Eds.), Children, Culture and Education (pp.25-41). New York: Springer.

STETSENKO, A. (2010). Teaching-learning and development as activist projects of historical Becoming: Expanding Vygotsky’s approach to pedagogy. Pedagogies: An International Journal, 5(1), 6-16.

STETSENKO, A. (2009). Vygotsky and the conceptual revolution in developmental sciences: Towards a unified (non-additive) account of human development. In M.Fleer, M. Hedegaard, J.Tudge \& A.Prout (Eds.) World Year Book of Education. Constructing childhood: Global-local policies and practices (pp. 125-142). Routledge.

STETSENKO, A. (2008). From relational ontology to transformative activist stance: Expanding Vygotsky's (CHAT) project. Cultural Studies of Science Education, 3, 465-485.

STETSENKO, A., \& ARIEVITCH, I. (2004). The self in cultural-historical activity theory: Reclaiming the unity of social and individual dimensions of human development. Theory \& Psychology, 14 (4), 475-503.

STETSENKO, A., \& VIANNA, E. (2009). Bridging developmental theory and educational practice: Lessons from the Vygotskian project. In O.Barbarin and B.H.Wasik (Eds.), Handbook of Child Development and Early Education. Research to Practice (pp. 38-54). NY: Guilford.

WILLINSKY, J. (1988). Learning to divide the world: Education at empire's end. Minneapolis: University of Minnesota.

WINSTON, A. S. (2004). Introduction: Histories of psychology and race. In A. S. Winston (Ed.), Defining difference: Race and racism in the history of psychology (pp. 3-18). Washington, DC: American Psychological Association.

VIANNA, E. (2009). Collaborative transformations in foster care: Teaching-learning as a developmental tool in a residential program. Saarbrücken: VDM Verlag Dr. Müller. 
VIANNA, E., HOUGAARD, N., \& STETSENKO, A. (2014). The dialectics of collective and individual transformation. In A. Blunden (ed.), Collaborative Projects (pp. 59-87). Leiden, the Netherlands: Brille Publishers.

VIANNA, E., \& STETSENKO, A. (2017). Expanding student agency in the introductory psychology course: Transformative activist stance and critical-theoretical pedagogy. In Obeid, R., et al. (eds.). How We Teach Now: The GSTA Guide to Student-Centered Teaching. http://teachpsych.org/ebooks/

VIANNA, E., \& STETSENKO, A. (2014). Research with a transformative activist agenda: Creating the future through education for social change. In J. Vadeboncoeur (ed.), Learning in and across Contexts: Reimagining Education. National Society for the Studies of Education Yearbook, 113(2), pp. 575-602.

VIANNA, E., \& STETSENKO, A. (2011). Connecting learning and identity development through a transformative activist stance: Application in adolescent development in a child welfare program. Human Development, 54, 313-338. 